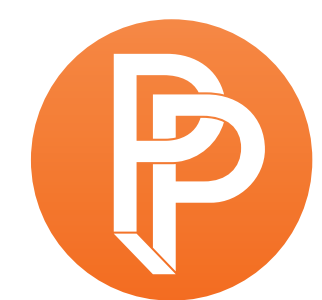

PERFORMANCE

PHILOSOPHY

\title{
EVERY TEXT IS A PERFORMANCE: A PRE-HISTORY OF PERFORMANCE PHILOSOPHY
}

DAVID KORNHABER THE UNIVERSITY OF TEXAS AT AUSTIN

In American Drama: The Bastard Art, a study of the role that antitheatrical prejudice has played in the formation of the American dramatic canon, Susan Harris Smith draws attention to a curious exchange that happened in the pages of Educational Theatre Journal during the 1950s. In a series of articles and letters that spanned multiple years, sides were drawn between those, in the words of the debates' participants, "who respect a play only for... ideas which can be analyzed philosophically" and those who saw theatre instead as an "art of performance" (Smith 1997, 15051). For Smith, the main point of interest in this dialogue is the contentiousness over the very idea of drama's place in the academy and the disagreements over its proper position. But looking from a perspective aligned with the interests of performance philosophy, what is equally intriguing is the way in which those assertions of merit that do surface within the discussion are divided between camps that are seen as mutually opposed and incommensurable: there is the text and there is the performance, the one an art of ideas and the other an art of perception and emotion. Within the dialogue that Smith chronicles, it is strongly asserted by some discussants that dramatic material has a philosophical purpose-yet that purpose is not extended to the performance of the same plays. Performance here represents a kind of endpoint to philosophy: open up a text to staging and its larger intellectual resonances are sure to disappear. From the standpoint of these mid-century academics, the issue is not that drama cannot function philosophically; it is that performance supposedly cannot. Or, put another way: a text can sustain philosophical investigation, but not a stage. 
My purpose in this essay is to take a few first steps toward constructing what I will call a prehistory of performance philosophy. It is an investigation premised on a single central question: why now? That is, why in the early twenty-first century has performance philosophy begun to emerge as a self-defined field when its essential intellectual ingredients have been available in academic studies of theatre and performance for decades, if not centuries? Even the example taken above comes tantalizingly close to completing the equation. Simply take the interest in drama's capacity for "ideas which can be analyzed philosophically" and combine it with the assertion of theatre as an "art of performance" and you have a perspective on the specifically philosophical potential of live performance that would easily resonate with those scholars today who have turned to performance philosophy as a field of prominent concern. The history of the academic study of dramatic literature, I intend to argue, is studded with such near-misses, marked by periods of sustained interest in the philosophical potential of drama and theatre that never quite went so far as to extend the same philosophical qualities to the act of performance itself. There are, inevitably, occasional counterexamples, and many of the tenets of performance philosophy can and have been read back into the work of academics, practitioners, and theorists who might never have thought to adopt such an affiliation themselves. ${ }^{1}$ Yet nothing resembling the manner in which performance philosophy has recently emerged as a subfield - seeking formal recognition and struggling to define its disciplinary boundaries and methods - has previously occurred in the long history of studies which seek to bring philosophy and theatre together in some way. My supposition as to the nature of one of the strongest stumbling blocks to such perspectives emerging earlier in the scholarship, as I will attempt to develop here, has far less to do with academic perspectives on performance than one might initially think and far more to do with the perceived boundary points and limitations of philosophy itself. Put more directly: it may not be that performance was seen as being incapable of sustaining philosophy so much as that philosophy was seen as being unable to survive performance.

As a starting point of my pre-history, I will turn to Brander Matthews-a figure generally forgotten today but who bequeathed to those of us in the United States who are interested in studying performance philosophy something of great importance: a place in the academy. At least in America, Matthews, a professor in the English Department at Columbia University from the 1890 s to the 1920s, was the first collegiate faculty member devoted to studying and teaching dramatic literature. It is in no small part through his precedent that drama, and behind it the theatre proper, first began to enter the American university system. Even more apropos to our present concerns, Matthews was among the first within the academy to ascribe a central place for philosophy within dramatic literature-not just the classical drama of Greece or the tragedies of Shakespeare but all drama, even potentially the popular drama being produced all around him in turn-of-the-century New York. For many, he writes, the drama's "chief quality is that it enables them to disentangle the philosophy of the dramatist himself" (Matthews 1912, 3). Matthews of course did not specifically mean the kind of formal philosophical tracts that would have been studied by his colleagues in the Columbia Philosophy Department when he deployed the term in this way-but then again, neither do many of us when we discuss the philosophy in performance philosophy. He meant, instead, "a message of high importance" and a "vision of human life"-a broad but nonetheless serviceable definition and one open to the idea that a philosophy may be 
created in the theatre itself rather than simply conveyed through the theatre (Matthews 1910, 217). This should come as little surprise, though, as Matthews, as much as he was a professor in the Ivy League, was also very much a fixture of the theatre of his era. He was, in fact, a working playwright, most remembered in that capacity today for the fact that one of his plays, A Gold Mine (1887), has a prominent part in the plot of Theodore Dreiser's novel Sister Carrie (1900), wherein Carrie decides to pursue a career in the theatre while attending a performance of Matthews' work.

As a theatre professional, Matthews had no tolerance for those who saw in the drama's philosophical potential only an avenue for a kind of textually-based theorizing as it might be practiced by a philosopher proper. A work for the stage had to be, in his mind, first and foremost theatrical before it could think to take on any other purpose. "All the masterpieces of the dramatic art were originally written to be performed by actors, in a theater, and before an audience of the dramatist's own contemporaries," Matthews wrote $(1910, v)$. Therefore it is "to the actor and to the theatre" that the dramatist owes his first allegiance, and no degree of intellectual calling can "excuse him for any failure to master the technic of the dramaturgic art" (Matthews 1910, 218, 217). "This art," Matthews insisted of the drama, "does not lie wholly within the limit of literature"; it was an art as much of "oratory" as poetry, "gesture" and "pantomime" as much as logic or story (Matthews 1910, 1-2). The drama's inherent philosophical potential, in other words, had to find a way to accommodate itself to the realities of theatrical performancea structure wherein the "art of the playwright must ever be most intimately associated" with "the art of the actor" as well as "of the musician, of the painter, and of the sculptor" (Matthews 1910, 3). While acknowledging "the psychology, the philosophy, and the poetry which we now admire" in the greatest plays, Matthews asserts that even the most seemingly philosophical drama is always first and foremost a work for the stage (Matthews 1910, v). "It is impossible to consider the drama profitably apart from the theater in which it was born and in which it reveals itself in its completest perfection," he writes (Matthews 1910,3). This is not performance philosophy exactly, but it is close. Why did the field we are now trying to define not emerge then, in the aftermath of Matthews' views?

In a way we might say that it almost did, but it took such a different direction that few today would recognize the works that came after Matthews as true ancestors of today's scholars of performance philosophy. I am thinking here of that tradition within drama scholarship that follows from the work of Eric Bentley and his seminal 1946 treatise The Playwright as Thinker. Bentley is not the first figure one might think of as an inheritor to Matthews (he was all of eight years old when the famed Columbia professor retired), though he did hold the title of Brander Matthews Professor of Dramatic Literature during his own years teaching at the same institution in the 1950s. But intellectually, Bentley picked up on many of the most salient points of Matthews' scholarship, furthering his notion that drama is properly seen as a vehicle for "the philosophy of the dramatist himself." Bentley's central point in The Playwright as Thinker is that drama is a fundamentally intellectual genre, capable of containing great abstract thinking, a "river bed into which mighty ideas flow" as he later put it in The Life of the Drama (Bentley 1964, 113). The world of the stage is a world of ideas for Bentley, and Thinker is filled with comparisons 
between the drama of the modern era and the philosophical works of Kierkegaard, Nietzsche, and Sartre as well as more obscure philosophical figures like Georg Simmel. Although, to say the world of the stage is a world of ideas for Bentley is not quite right-the world of the stage as imagined in the pages of dramatic texts is a world of ideas for him. Of the actual stage, Bentley has relatively little to say. He acknowledges its importance-even speaking of the vitality of a kind of "psychic' contact between the living actor and his audience"-yet he engages only rarely and fleetingly with the actual conditions or histories of theatrical production (Bentley 2010, 288). His is primarily a study of dramatic literature and its writers, not of what happens when the great thinking of the great playwrights actually encounters an audience inside a theatre. For Bentley, it is only the great playwright who is the unspoken equivalent of the great philosopher-the actor, the performer, the actual figure of the theatre is but an unspoken accomplice, a communicator of the playwright's ideas. In one of Bentley's more extreme articulations, he declares that "The dramatist is a poet-that is, an imaginative writer of verse or prose-who transmits his work through gesturing elocutionists" (Bentley 2010, 288). Any other formulation he views explicitly as suspect. "When drama takes on the abstract character of pure music or pure dance it ceases to be drama; when, as a compromise, it tries to combine the abstract with the concrete it is invariably the drama, the words, that suffer," he writes (Bentley 2010, 283).

In Bentley's treatise begins a template for viewing the relationship of theatre, drama, and philosophy that would continue to be used for decades, always existing on the far side of the territory that would come to be claimed by performance philosophy, never quite anticipating its concerns. Perhaps the most influential application of the views Bentley pioneered can be found in The Theatre of Revolt by Robert Brustein, who studied at Columbia during Bentley's tenure there and who regarded The Playwright as Thinker as having "an untold influence on me" (Copeland 2008, 31). In Brustein's work, the connection between the theatre and philosophy becomes explicit and direct. Dramatists are here placed in the actual descent of philosophers, grouped into the same intellectual family-different species, same genus. "The modern drama," Brustein explains,

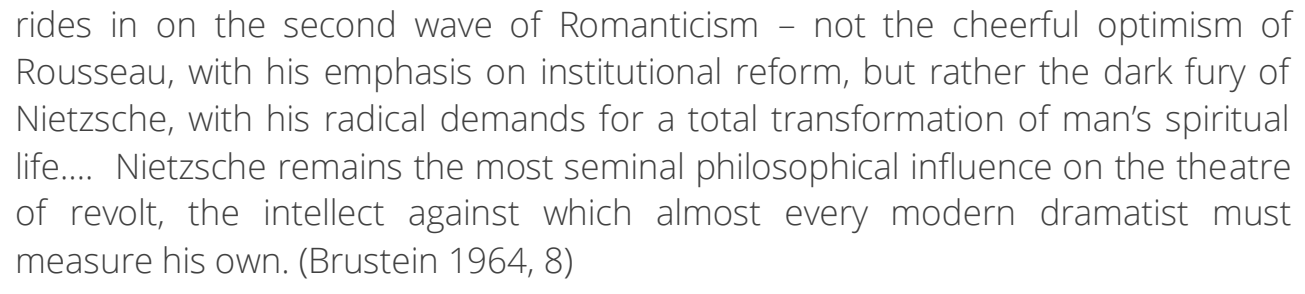

As with Bentley, the actual theatre of The Theatre of Revolt is again largely an imagined one: production and performance figure little into Brustein's seminal study. As Austin Quigley later observed about Brustein's work and the numerous subsidiary treatises that it inspired-what Quigley deems the "Theatre of $X$ " strain in drama scholarship_it is all resolutely and imperturbably textualist (Quigley 1985, 57). Here, actual theatre rarely appears and instead "textual patterns are asked to provide the basis for structural and thematic generalizations" (Quigley 1985, 57). Drama, for these critics and scholars, holds great philosophical potential, which is then extrapolated onto the theatre but only in the most abstract sense. We never get a 
taste of what philosophy might look like inside the playhouse, except as a refraction of what it looks like from inside the library. As Richard Gilman wrote in The Making of Modern Drama at the tail end of the Bentley-Brustein tradition, "Drama may in fact be a species of philosophy" (Gilman $2000,179)$. And what of theatre? And what of performance? This branch of the performance philosophy pre-history never quite thinks to ask those questions, does not even formulate them as such. For these interpreters, the philosophy expressed in performance can only ever be an articulation of the philosophy first contained within the text-and even that is a more direct formulation of the implicit assumptions of many of these works than they themselves ever actually declare.

What I find most curious about the performance lacuna within this tradition of philosophicallyminded scholarship on the drama is the fact that figures like Bentley and Brustein were very much invested in the theatre outside of the academic part of their careers. Both served legendarily as drama critics for The New Republic, which only scratches the surface of their direct involvement in the stage. ${ }^{2}$ Bentley, as one of the great English-language champions of Bertolt Brecht, knew the playwright-director intimately and worked extensively as a translator of his plays. He also wrote nearly a dozen original dramas of his own and was a longtime cabaret performer, on the basis of which he was elected to the New York Theater Hall of Fame. ${ }^{3}$ For Brustein, the theatre assumed an even more prominent place in his life's work. Founder of both the Yale Repertory Theatre and the American Repertory Theatre, he oversaw some 200 productions at the two institutions, including twelve that he directed and eight in which he acted. ${ }^{4}$ Bentley and Brustein were no strangers to the stageboards, yet the thought of systematically applying their views on drama's philosophical potential directly to the lived performance conditions of the stage never significantly entered into their work. They held an interest in philosophy and an interest in performance but never did the two fully cross: yet another near-miss in the pre-history of performance philosophy.

Of course, one cannot single out Bentley, Brustein, and their followers for uniquely holding text and stage apart. As William Worthen has observed in Print and the Poetics of Modern Drama, nearly the entire intellectual edifice of the study of dramatic literature is built on a resolutely textualist foundation, a view that has long since filtered into the common understanding of how theatrical performance "works." He describes this view as a "zombie-theory of drama, in which performance is only partly and provisionally inhabited by the transcendent work-of-art, which then moves on to seize other bodies" (Worthen 2005, 8). Performances, in other words, are only ever "incomplete 'interpretations' of the text" (Worthen 2005, 8). What is particularly fascinating in the special case of the Bentley-Brustein school-what I have elsewhere called "Drama and Philosophy $1.0^{\prime \prime}-$ is the degree to which philosophy is never allowed to cross this seemingly essential blood-brain barrier. ${ }^{5}$ The environments of text and stage must be kept apart, with philosophy squarely residing within the former and only being discernable in the latter insofar as it enacts the mandates of the text. Production is here a means of interpreting meaning but never a vehicle for its overt and original creation. It would be easy to see this perspective as evidencing a prejudice against performance, were it not so clear biographically how much Bentley and Brustein were enamored of the live stage. And it is not as though there were calls for a greater 
philosophical attention to performance which they resisted: the idea of performance being a vehicle for philosophical investigation was simply not an overt or widespread part of the discourses in which they participated, either as academics or practitioners. Performance philosophy was not yet ready to exist.

Or rather, not yet ready again. Because there are two sides to the historical narrative of this centaur-like discipline. There is the history wherein performance has never quite been married to philosophy, despite several near engagements. And there is the history in which philosophy has steered clear of performance-as an object of inquiry, yes, but also as a method of articulation. Those few contemporary philosophers like Paul Woodruff (2008) and Tzachi Zamir (2014) who have ventured recent studies of the stage (The Necessity of Theater: The Art of Watching and Being Watched and Acts: Theater, Philosophy, and the Performing Self, respectively) have both reflected on the paucity of philosophical literature on the topic, all the more consternating when one considers the volumes of philosophical treatises that have been written on film or the visual arts. Jonas Barish (1981) would of course point us toward the antitheatrical prejudice, and Zamir in particular seconds his assessment. Yet there is more here: there was a time when philosophy arguably had no such prejudices at all, and there was a point at which the discipline changed its stance. As so often happens in discussions of philosophy, my thinking here goes back to Plato, the figure who arguably bequeathed the field its textualist penchant and the originator of the antitheatrical prejudice itself. But the key text in this story is not The Republic, on which Barish and so many others have focused, but the Phaedrus, wherein Socrates-by definition, the last of the Pre-Platonic philosophers-declares writing to be the natural enemy of philosophy and performance its natural ally. Writing, he says "will introduce forgetfulness into the soul of those who learn it," and its advocates "have not discovered a potion for remembering, but for reminding" (Plato 1995, 79). Unlike actual debate and conversation, it cannot adapt and respond to the moment. "If you question anything that has been said because you want to learn more, it continues to signify just that very same thing forever" (Plato 1995, 80-81).

This primal scene of encounter between the written and the spoken as methods of pursuing philosophy has come back into view recently in Martin Puchner's The Drama of Ideas, which takes seriously Plato's dialogues as drama and thus must contend with the unique relationship they create between text and performance. In Puchner's reading, Plato essentially rebuts his mentor through the very text of the dialogue in which Socrates' criticisms are contained. The Platonic dialogue, Puchner writes, is able to "model an interactive relation between actor and audience," such that "the theatrical dimension of Plato's dialogues, their particular type of participatory performance, is activated whether they are actually performed or not" (Puchner 2010, 29). Everything a performance can do, a text can do better, Plato essentially contends-with the added benefit that a text can do it forever. The philosopher who performs his philosophy in the agora does so in the moment; the philosopher who records his philosophy in writing does so for posterity. We know of Socrates because of Plato; we know of Plato because of writing. In this sense, as many have argued, Plato's emergence is part of a larger cultural shift in the Hellenic world that has today become so widespread as to be all but unnoticeable: the shift from a culture of orality to one of literacy. "Plato, searching for a suitable means of disseminating his own 
'ideas' or beliefs, saw purpose in using the dialogue, an ostensibly oral phenomenon, for what was to be a reader's corpus of written prose," writes Jackson Hershbell (1995, 31). In this sense, we might even say that writing and performance are two competing technologies born of differing historical epochs, epochs that meet face to face in the encounter between Socrates and Plato. Theatre-in Paul Woodruff's definition as "the art of watching and being watched"-is a technology of dissemination, a means of communicating to a crowd, just as writing is. But writing traverses time without supposedly ever changing. (Hence its deadness to Socrates - the way it "continues to signify just that very same thing forever.") Philosophy becomes attached to this technology, begins to think that it can only exist in this form. Even theatre, paradoxically, eventually falls under its spell, convinced that its meaning resides fundamentally in its texts. As Worthen writes of drama in the age of print culture, "Dramatic performance has increasingly come to be understood on the model of print transmission, as a reproduction or reiteration of writing, as though performance were merely a new edition of the substantial identity of the script" (Worthen 2005, 8). Text becomes the only possible medium of truth.

Far be it for a couple of drama scholars and theatre critics to up-end more than two millennia's worth of thinking about the primacy of texts or their essential connection to philosophical work. The idea of a philosophy or a form of philosophizing that exceeds the mandate of the text was a radical shift in the history of ideas-and although a serious critical engagement with the fact of performance is arguably a key part in what made this transition possible, it does not necessarily follow that drama scholars would be the ones to take on the work of attempting this leap. If philosophy, on the whole, did not seem conceivable outside the text even for philosophers, why would it seem so for theatre scholars? I've asked here why performance philosophy did not emerge from the Columbia English Department in the 1910s or the 1950s or the 1960s, when Mathews and Bentley and Brustein, taking just three examples, began to touch on similar terrain. But I might equally ask why it did not emerge in the Philosophy Department during these same times? Or a century earlier? Or a few millennia before that in the agoras of Athens? It is not just that performance after Plato did not seem capable of sustaining or creating original philosophical inquiry; nothing else did either except for writing. Even when individual philosophers recognized the limitations of literacy to the project of philosophy broadly conceived-and Nietzsche's "Truth and Lying in an Extra-Moral Sense" ([1873] 1999) is nothing if not such a recognition, doubting the efficacy of any language to the pursuit of philosophical truth-few if any ventured to attempt philosophy by another means. Nietzsche's grappling with text and language led him to radically change the way in which philosophy was written but not the fact that it was written: he still wrote books of philosophy, he just wrote them differently. Historically, from Plato onwards, text was the only broadly legitimized vehicle of philosophy.

Until it was legitimized no longer. Go into any philosophy department today and you'll be hard pressed to find a scholar working in a medium other than text; the very idea might strike many as absurd. ${ }^{6}$ But ask around in that department and you are almost sure to find someone willing to enumerate the problems of textuality and the intellectual limitations of language itself in the expression of philosophical discourse. It goes without saying that this is a sea-change. The opening of writing, language, and textuality to the same philosophical investigation that they 
themselves had long been used to carry represents a recursive investigation into the structuring principles of philosophy as a discipline itself: an opening at least two millennia in the making. The arguments here about the inherent quandaries of the text are too extensive and too wellknown to fully rehearse. And it demands to be acknowledged that the impact and extent of the intellectual shift represented by the avenging figures of deconstruction and poststructuralism or the relativists of reader response theory loom far larger within the literary humanities than in other disciplines. While literary scholars spent a generation or more under the sway of a certain brand of philosophical skepticism given the single moniker of "theory," such interpretive prescriptions never reached the same ubiquity within the discipline of philosophy itself. Yet the fact remains that the blood-brain barrier between text and performance has been made more permeable in today's academy than at any time in the history of the modern university at least. To take just one recent example that originates from within the citadel of the formal discipline of philosophy rather than the outposts of critical theory in the humanities, I will quote from Nicholas Rescher, distinguished university professor of philosophy at the University of Pittsburgh:

\section{A text is prismatic in nature, it reflects different features depending upon the point of view from which it is regarded. The process at issue has two inputs: text and context. And interpretations themselves change the context. They form part of a developmental feedback process. (Rescher 2010,7)}

Or, as we might say it over on the humanities side of the campus: every text is uncertain, every text is contingent, every text is changed in the moment of its enactment. Every text, in other words, is a performance.

Asked to quickly recount the most salient intellectual origin point of performance philosophy, one might think of the rise of performance studies and the late-twentieth-century "performative turn" in philosophy and the humanities more broadly. Yet it is my contention that the rethinking of the nature of the text during the advent of poststructuralism was an event of at least equal importance, in large part due to the particular history that had developed in the study of theatre and philosophy up to that point. For much of the twentieth century, philosophy had played a central role in the academic investigation of dramatic playtexts. It might even be said that such texts brokered their entry into academic recognition on the basis of their supposed linkages to philosophy, "the queen of the disciplines" as Puchner once described the field (Puchner 2013, 542). From Matthews' reflections on "the philosophy of the dramatist himself" to Bentley's insistence on the playwright's primary intellectual role, drama had long staked a claim to philosophical significance as proof of its academic viability. By the 1960s and 1970s, such a perspective had arguably achieved majority status, at least in the United States-in Brustein's 1964 monograph, in Gilman's 1972 treatise-while international examples also proliferated, from Martin Esslin's grappling with existentialist philosophy in The Theatre of the Absurd to the actual theatre of the actual existentialists themselves. It was a truism in the academic study of dramatic texts that the creation and articulation of philosophical positions played some part in their interest and importance, a meaning that was supposedly grounded-like all theatrical meaning, according to the common perceptions on the issue as observed by Worthen-in the text itself. 
When the supposedly insurmountable differences between text and performance that had constrained such meaning to the textual side of this dual literary-theatrical form at last came into question, the idea of a transposition of philosophical meaning from the realm of dramatic text to the realm of theatrical performance was available to be had. Philosophical purpose did not need to be newly ascribed to theatre and performance; it just needed to be moved.

What we might call the soft version of this transition has been well underway in the realm of theatre scholarship proper, where it has become a not uncommon move to reveal the philosophical potential or philosophical origins of some strictly theatrical enterprise. Joseph Roach's famous statement in The Player's Passion that "the history of the theatre is a history of ideas" is an early articulation of this theme, what we might call a recognition of the philosophy of the playhouse (Roach 1993, 11). Darren Gobert's The Mind-Body Stage: Passion and Interaction in the Cartesian Theatre (2013), which covers everything from acting technique to theatre design in its investigation of Descartes' legacy for the stage, represents a more recent incarnation. And this newly permitted interaction is almost literalized in Freddie Rokem's Philosopher and Thespians: Thinking Performance (2010), which uncovers the newly allowed history of philosophical and theatrical interactions, a literal shaking of hands between practitioners of the two disciplines.

The "hard" version of this transition is performance philosophy, which I would argue owes as much to the history of drama and theatre studies particularly in the Bentley-Brustein tradition as it does to the more recent, seemingly more relevant, and clearly more disciplinarily aligned field of performance studies. Few scholars who identify with performance philosophy as a field likely think of themselves as the explicit inheritors of figures like Bentley or Brustein (let alone Matthews), who are rarely cited today even in drama and literary journals. But no one ever really remembers their ancestors: we just live in the world they created. It too was once a radical proposition to claim a philosophical potential for a dramatic text, to claim an intellectual status and a metaphysical purpose for people who spent their time writing plays that were performed in theatres. Just as it is a relatively new proposition in the history of ideas to claim an explicit metaphysical or epistemological or ethical mandate for those who spend their time acting in them-or even not acting in them, instead performing unmoored from a dramatic text. To say that the work of performance is fundamentally philosophical: to my mind, that is the basic proposition being tested by performance philosophy. I know the converse to be true (that the work of philosophy is fundamentally performative), on no less an authority than Socrates. And I have a suspicion that this formulation is correct as well, in part on the model of those figures of Drama and Philosophy 1.0 and the work they did to first bring philosophy and theatre into academic contact. They probably never dreamt of a field like performance philosophy, but they helped show the way to it all the same. 
${ }^{1}$ The project of reading performance philosophy into or out of the work of theorists and thinkers who wholly or partially predate the formation of the discipline is in fact one of the goals of the Performance Philosophy book series from Palgrave Macmillan, which recently published titles on Žižek and Adorno. On the practitioner side, one thinks of the longstanding tradition of reading Beckett's stage work philosophically despite the playwright's well-known protests that he could "never understand" philosophy. On the former, see Cull, Lagaay, and Rokem 2014; Chow and Mangold (2014); Daddario and Gritzner (2014). On the latter see Van Hulle and Nixon (2013), 128. Examples of such philosophically-driven readings of Beckett can be found, for instance, in Lane (2002).

2 For a collection of Bentleys New Republic reviews and other essays, see Bentley (1968). Brustein's reviews can be found primarily in three volumes in addition to his multiple volumes of essays. See in particular Brustein (1965), Brustein (1987), and Brustein (2006).

${ }^{3}$ For an account of Bentley's activities as a theatre practitioner see in particular Kalb (2006).

${ }^{4}$ For more on Brustein's stage work and legacy, see, for instance, Brustein (1981), Plotkins (2005), and Holmberg (1999).

5 For a further discussion of Matthews, Bentley, and Brustein in this regard, see Kornhaber (2013).

${ }^{6}$ There are, of course, exceptions to this rule. Richard Shusterman's work in somaesthetics stands out as a mode of philosophical thinking deeply invested in the conditions and practices of the body. See in particular Shusterman (2008) and Shusterman (2012).

\section{Works Cited}

Barish, Jonas A. 1981. The Antitheatrical Prejudice. Berkeley: University of California Press.

Bentley, Eric. 2010. The Playwright as Thinker: A Study of Drama in Modern Times. Minneapolis: University of Minnesota Press.

- - 1968. What is Theatre? Incorporating The Dramatic Event and Other Reviews, 1944-1967. New York: Atheneum.

1964. The Life of the Drama. New York: Hal Leonard Corporation.

Brustein, Robert. 2006. Millenial Stages: Essays and Reviews, 2001-2005. New Haven: Yale University Press.

___. 1981. Making Scenes: A Personal History of the Turbulent Years at Yale, 1966-1979. New York: Random House.

1965. Seasons of Discontent: Dramatic Opinions, 1959-1965. New York: Simon and Schuster.

. 1987. Who Needs Theatre: Dramatic Opinions. New York: Atlantic Monthly Press.

(1961) 1964. The Theatre of Revolt: An Approach to the Modern Drama. Boston: Little.

Cull, Laura, Alice Lagaay, and Freddie Rokem. 2014. "Series Preface." In Encounters in Performance Philosophy, edited by Laura Cull and Alice Lagaay, viii-x. Basingstoke UK: Palgrave Macmillan.

Chow, Broderick, and Alex Mangold, eds. 2014. Žižek and Performance. Basingstoke UK: Palgrave Macmillan.

Copeland, Roger. 2008. "The Critic as Thinker: A Discussion at the Philoctetes Center of New York Center." American Theatre 25 (2): 31.

Daddario, Will, and Karoline Gritzner, eds. 2014. Adorno and Performance. Basingstoke UK: Palgrave Macmillan. 
Gilman, Richard. (1972) 2000. The Making of Modern Drama: A Study of Büchner, Ibsen, Strindberg, Chekhov, Pirandello, Brecht, Handke. New Haven: Yale University Press.

Gobert, R. Darren. 2013. The Mind-Body Stage: Passion and Interaction in the Cartesian Theatre. Stanford: Stanford University Press.

Hershbell, Jackson P. 1995. "Reflections on the Orality and Literacy of Plato's Dialogues." In The Third Way: New Directions in Platonic Studies, edited by Francisco J. Gonzalez. Lanham MD: Rowman and Littlefield.

Holmberg, Arthur, ed. 1999. The Lively ART: A Treasury of Criticism, Commentary, Observation, and Insight from Twenty Years of the American Repertory Theater. Chicago: Ivan Dee.

Kalb, Jonathan. 2006. "A Critic Has Praise for a Playwright (Himself)." The New York Times, November 12.

Kornhaber, David. 2013. "Introduction: Drama and Philosophy 2.0." Modern Drama 56 (4): 419-33. http://dx.doi.org/10.3138/md.56.4.Intro.

Lane, Richard, ed. Beckett and Philosophy. Basingstoke UK: Palgrave Macmillan.

Matthews, Brander. 1912. The Development of the Drama. New York: Scribner.

1910. A Study of the Drama. New York: Houghton.

Plato. 1995. Phaedrus. Translated by A. Nehamas and P. Woodruff. Indianapolis: Hackett Publishing Company.

Neitzsche, Friedrich. (1873) 1999. "On Truth and Lying in a Non-Moral Sense." In The Birth of Tragedy and Other Writings, translated by Ronald Speirs, edited by Raymond Geuss and Ronald Speirs, 139-153. Cambridge: Cambridge University Press.

Plotkins, Marilyn. 2005. The American Repertory Theatre Reference Book: The Brustein Years. Westport CT: Praeger Publishers.

Puchner, Martin. 2013. "Afterward: Please Mind the Gap Between Theatre and Philosophy." Modern Drama, 56 (4): 542. http://dx.doi.org/10.3138/md.S85.

___. 2010. The Drama of Ideas: Platonic Provocations in Theater and Philosophy. Oxford: Oxford University Press.

Quigley, Austin E. 1985. The Modern Stage and Other Worlds. New York: Methuen.

Rescher, Nicholas. 2010. Philosophical Textuality: Studies on Issues of Discourse in Philosophy. Frankfurt: Walter de Gruyter

Roach, Joseph. 1993. The Player's Passion: Studies in the Science of Acting. Ann Arbor: University of Michigan Press.

Rokem, Freddie. 2010. Philosophers and Thespians: Thinking Performance. Stanford: Stanford University Press.

Shusterman, Richard. 2012. Thinking Through the Body: Essays in Somaesthetics. Cambridge: Cambridge University Press.

___. 2008. Body Consciousness: A Philosophy of Mindfulness and Somaesthetics. Cambridge: Cambridge University Press.

Smith, Susan Harris.1997. American Drama: The Bastard Art. Cambridge: Cambridge University Press.

Van Hulle, Dirk, and Mark Nixon. 2013. Samuel Beckett's Library. Cambridge: Cambridge University Press.

Woodruff, Paul. 2008. The Necessity of Theater: The Art of Watching and Being Watched. Oxford: Oxford University Press.

Zamir, Tzachi. 2014. Acts: Theater, Philosophy, and the Performing Self. Ann Arbor: University of Michigan Press.

Worthen, W.B. 2005. Print and the Poetics of Modern Drama. Cambridge: Cambridge University Press. 


\section{Biography}

David Kornhaber is Assistant Professor of English and Comparative Literature at the University of Texas at Austin. He is the author of The Birth of Theatre from the Spirit of Philosophy: Friedrich Nietzsche and the Development of the Modern Drama (Northwestern University Press, 2016). His work has appeared in PMLA, Modern Drama, Theatre Journal, Theatre Research International, and Philosophy and Literature, among other journals. He has served as guest editor of Modern Drama for a special issue on drama and philosophy, as assistant editor for Theatre Survey, as an Affiliated Writer with American Theatre, and as a contributor to the theatre sections of The New York Times, The Village Voice, and The New York Sun.

(c) 2015 David Kornhaber

c) (7)(2) Except where otherwise noted, this work is licensed under a Creative Commons Attributioncc) Non No SA 